Original Research

\title{
Influence of Human Activity on Surface Water Quality in Moravian Karst
}

\author{
Dana Hubelova ${ }^{1 *}$, Jitka Mala ${ }^{2}$, Alice Kozumplikova ${ }^{1}$, Katerina Schrimpelova ${ }^{2}$, \\ Hana Hornova ${ }^{3}$, Petr Janal $^{3}$
}

${ }^{1}$ Faculty of Regional Development, Mendel University in Brno, Brno, Czech Republic

${ }^{2}$ Faculty of Civil Engineering, Brno University of Technology, Brno, Czech Republic

${ }^{3}$ Czech Hydrometeorological Institute, Brno Branch Office, Brno, Czech Republic

Received: 17 September 2019

Accepted: 14 November 2019

\begin{abstract}
Water systems are significant but vulnerable components of karst areas. Our paper presents the results of a multidisciplinary approach focused on the identification of a whole complex of influences that can affect water quality in a karst area. We delineate results on the example of Jedovnicky brook, representing one of the main watercourses bringing water and, concurrently, pollution from the non-protected area out of karst to the Protected Landscape Area Moravian Karst (Czech Republic). The main aim is to present the development of human impacts on water quality in the period 1931 and 2010. The development of physical-chemical status (monitoring campaigns from 1949 to 2014; mass flows of $\mathrm{BOD}, \mathrm{NH}_{4}-\mathrm{N}, \mathrm{NO}_{3}-\mathrm{N}$, and $\mathrm{PO}_{4}-\mathrm{P}$ ) as well as historical land use and demographic changes were assessed. Agricultural activities, population growth and changes in settlements were identified as the main sources of the pollution in the past. Agricultural activities have undergone major positive changes - especially in the way of management and the use of fertilizers. Currently, the strong suburbanization trend (rising population after the year 2000, the expanding built-up areas, increasing amount of municipal wastewaters) is the most important risk factor for the deterioration of Jedovnice brook water quality and, as a result, karst water quality.
\end{abstract}

Keywords: environment quality, karst waters, mass flows, population growth, land use changes

\section{Introduction}

Human activities, population growth and settlements pose a threat of degradation for the natural environment and especially for karst water [1, 2]. Water is a key factor in the formation and occurrence of karst phenomena. A number of surface watercourses flow

*e-mail: dana.hubelova@mendelu.cz to the karst areas from the non-protected areas. These watercourses almost instantly disappear into the underground at the geological boundary of the karst area. The hydrological regime of these watercourses in the karst area is very complicated. Underground spaces are collectors gathering water from surface flows. These ground waters have limited filtration and self-cleaning capability that can result in rapid transmission of the potential contamination and subsequently threat to drinking water sources. Human 
activities in the landscape act on karst areas both directly (speleological activities, visiting caves) and indirectly (agriculture, transport, mining, pollution of surface karst water by wastewater [3]). Human activities and land use outside the karst region play a very important role and influence significantly the karst area. Any inappropriate surface interventions eventually negatively affect the situation and developments in the underground. These effects are reflected in changes in a hydrochemical composition of karst waters $[4,5]$. Significant contamination with organic substances and nutrients was observed. The contamination leads to water eutrophication and represents numerous hazards both on the surface and in the karst underground $[5,6]$.

A study of underground karst watercourses confirms that agricultural activities, sewage from settlements and residential areas are the main sources of nitrogen and phosphorus [7]. In the study area with predominantly urban land use and septic systems, they contribute $48 \%$ and $22 \%$, respectively of the estimated total annual nitrogen load to groundwater, which is $294,400 \mathrm{~kg} \mathrm{~N} / \mathrm{yr}$. In the study area with predominantly agricultural land use, livestock operations and crop fertilizers contribute $50 \%$ and $13 \%$, respectively [8].

The risks of contamination of surface and subsequent underground water in the Moravian karst are primarily caused by:

1. Agriculture (particularly fish farming and fertilization of fields).

2. Contamination by wastewater from municipalities that lack a wastewater treatment plant (WWTP; particularly seeping septic tanks, cesspits, and domestic WWTPs).
3. Construction of new residential buildings (particularly increasing demands related to drinking water and wastewater management [9]).

There is a serious fact that in order to maintain a high quality of surface water in a protected landscape area, protection zones throughout the whole catchment area are to be defined. This issue is demonstrated on the example of the catchment area of Jedovnicky brook, which represents one of the main watercourses that brings water and concurrently pollution from the non-protected area out of karst to the Protected Landscape Area Moravian Karst (PLA MK). This topic is presented in the form of a multidisciplinary approach trying to capture the whole complex of influences that can affect water quality.

\section{Material and Methods}

The study area of Jedovnice Brook is situated $20 \mathrm{~km}$ northeast of the city of Brno and covers the cadastral areas of six municipalities within the district of Blansko. Jedovnice Brook belongs to the Morava River and Danube River basin draining water to the Black Sea. The area that belongs to the catchment area of Jedovnice Brook is $31.50 \mathrm{~km}^{2}$. Jedovnice Brook originates from four brooks (Krasova, Kotvrdovice, Senetarov and Podomi), which rise in agricultural landscape and flow through the villages with WWTPs or with simple settling tanks. These four brooks flow into the system of five Jedovnice ponds: Budkovan (7.07 ha), Dubovy (0.68 ha), Dymak (0.76 ha), Olsovec (42.00 ha) and Vrbovy (3.80 ha). Finally, Jedovnice

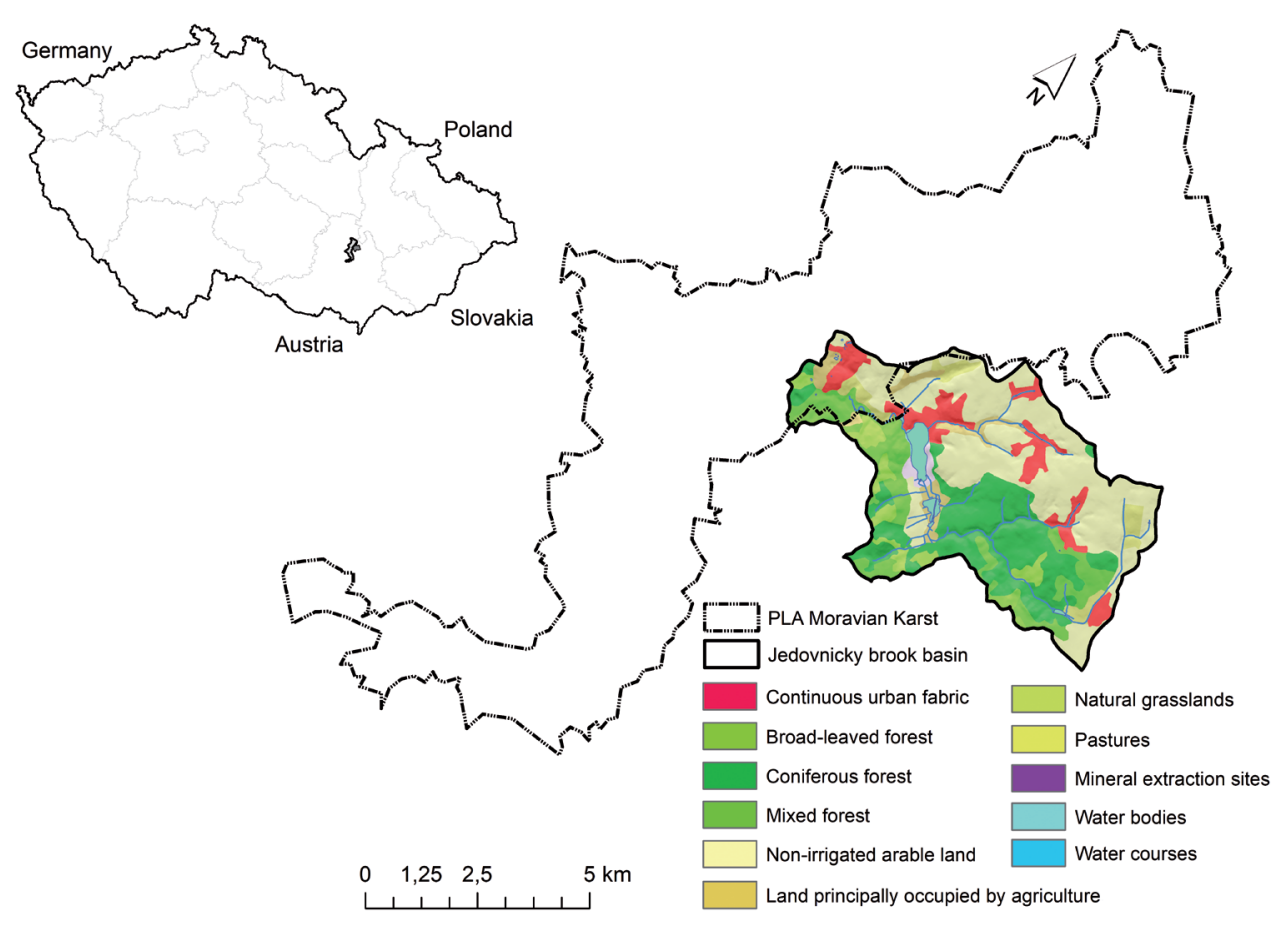

Fig. 1. Localization and CORINE land cover classes of the Jedovnice Brook basin in the context of PLA MK. Source: based on ArcCR500 and CORINE2018, CENIA.cz 
brook enters the PLA MK and sinks in the Rudice Swallow Hole as the studied watershed endpoint (Fig. 1). The Jedovnice Brook flows through the cave system of Rudice Swallow outside the basin and springs to the surface again behind Bull Rock Cave after $5.8 \mathrm{~km}$ [6]. The PLA Moravian Karst was established in 1956.

The study area belongs to the geomorphological complex of Drahany highlands and sub-complexes Konice highland and Moravian karst. The study area belongs geologically to the Bohemian Massif. The most represented rocks in the area are greywackes. A significant part, especially along watercourses, consists of alluvial sediments. The western part is represented by Paleozoic limestones of Moravian Karst. The most spread type of soil is Cambisol, with the karst part represented by Rendzina soil type.

The current land use of the basin consists of the mixture of forests (1 $724 \mathrm{ha}$ ), arable land (1 $198 \mathrm{ha}$ ), permanent grasslands (227 ha), water bodies ( $74 \mathrm{ha}$ ) and urban areas (354 ha) [11]. Ecological stability expressed by coefficient of ecological stability is 1.38 and the landscape of the basin can be characterized as balanced landscape where the technical objects are relatively in line with preserved natural structures resulting in lower need of energy-material inputs [10]. The localization and CORINE land cover classes of the Jedovnice Brook basin in the context of PLA MK is shown in Fig. 1.

Jedovnice Brook is already highly polluted before entering the territory of PLA MK. However, it retains self-cleaning ability on the surface. Before it falls into the karst underground, there is a significant reduction in both concentrations and mass flows of the pollutants observed [12]. Still, Jedovnice brook has been in the long-term perspective affected by human activities. The water flow rate has been influenced by the regular filling and discharging of the Olsovec and Budkovan ponds in the Jedovnice municipality. These ponds also affect the water temperature throughout the whole year. Ice occurrence influences the water flow during winter.

The water catchment area of Jedovnice brook drains cadastral areas of the above-mentioned six municipalities with a total population of 5,440 people and an average population density of 98.2 inhabitants $/ \mathrm{km}^{2}$. The wastewater treatment started after 1998 when a two-stage WWTP was built in Jedovnice. In 2013, the intensification of WWTP and sewerage network was initiated and the four municipalities of Jedovnice, Krasova, Rudice, and Senetarov were attached. Since this year, the discharge of treated wastewater into the stream has increased. Concerning the other municipalities in the PLA, Podomi and Krasensko have their own WWTPs, while there is only a simple settling tank in Kotvrdovice. The administrative division, localization of all WWTPs, drainage system and water bodies are shown in Fig. 2.

Within the Czech Hydrometeorological Institute, individual periods are evaluated, which are then used for data processing. In the past, it was the reference period 1931-1960, then 1931-1980 and it is now the period 1981-2010 - especially for the calculation of average daily flows (x-day flow; the average daily flow rate reached or exceeded during $\mathrm{x}$-days per a year). For the determination of annual flows (x-year flow;

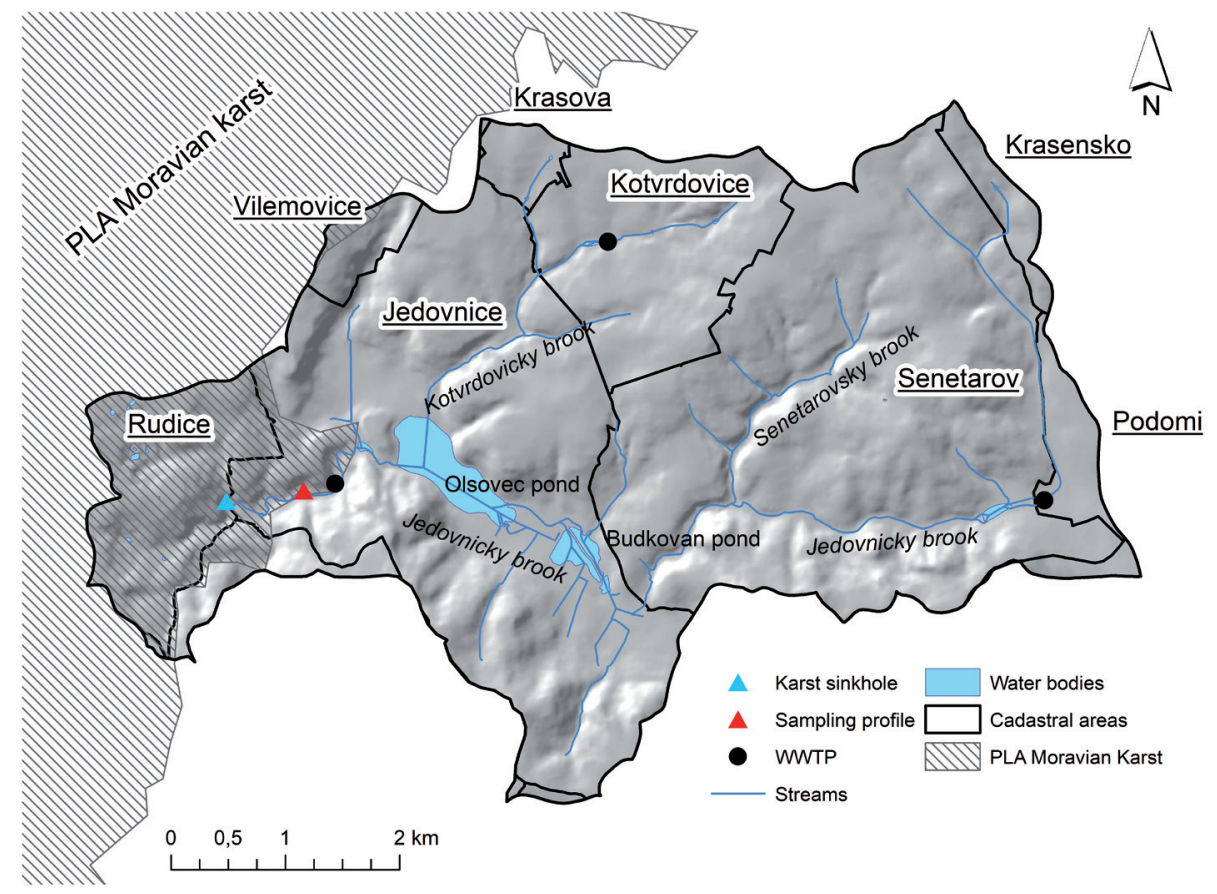

Fig. 2. Jedovnice Brook basin - administrative division with water courses system, localization of all waste water treatment plants and sampling profile.

Source: based on ArcCR500 and CENIA.cz 
Table 1. Basic hydrological characteristics of the target catchment area.

\begin{tabular}{|c|c|c|c|c|c|}
\hline Hydrological period & $1931-1960$ & $1931-1980$ & $1981-2010$ & & \\
\hline Average precipit. [mm] & 636 & 657 & 641 & & \\
\hline Average drain height $[\mathrm{mm}]$ & 134 & 117.21 & 137.13 & & \\
\hline Average flow $\left[\mathrm{m}^{3} / \mathrm{s}\right]$ & 0.121 & 0.117 & 0.123 & & \\
\hline $\mathrm{x}$-day flow $\left[\mathrm{m}^{3} / \mathrm{s}\right]$ & $1931-1960$ & $1931-1980$ & $1981-2010$ & & \\
\hline 30 & 0.300 & 0.3200 & 0.366 & & \\
\hline 90 & 0.121 & 0.1200 & 0.133 & & \\
\hline 180 & 0.058 & 0.056 & 0.043 & & \\
\hline 270 & 0.028 & 0.029 & 0.019 & & \\
\hline 364 & 0.0055 & 0.003 & 0.0014 & & \\
\hline $\mathrm{x}$-year flow $\left[\mathrm{m}^{3} / \mathrm{s}\right]$ & $\begin{array}{c}\text { 1931-1960 } \\
\text { uninfluenced }\end{array}$ & $\begin{array}{c}\text { 1931-1980 } \\
\text { uninfluenced }\end{array}$ & $\begin{array}{l}\text { 1931-1980 } \\
\text { influenced }\end{array}$ & $\begin{array}{c}\text { 1980-2010 } \\
\text { uninfluenced }\end{array}$ & $\begin{array}{l}\text { 1980-2010 } \\
\text { influenced }\end{array}$ \\
\hline 1 & 3.0 & 4.0 & 1.0 & 3.5 & 0.8 \\
\hline 2 & 4.9 & 6.0 & 1.48 & 5.5 & 1.3 \\
\hline 5 & 8.1 & 9.5 & 2.68 & 8.5 & 2.5 \\
\hline 10 & 11.0 & 12.5 & 4.18 & 11.5 & 3.9 \\
\hline 20 & 14.0 & 15.5 & 6.35 & 15.0 & 6.1 \\
\hline 50 & 20.0 & 20.5 & 10.54 & 19.5 & 10.0 \\
\hline 100 & 24.0 & 25.0 & 15.0 & 24.0 & 14.5 \\
\hline
\end{tabular}

Source: data provided by the Czech Hydrometeorological Institute [13]

the smallest average daily flow rate reached or exceeded once every x-years), a wide range of observation is used at the specific station and also the actual characteristics of the river basins such as woodland, drainage coefficient, specific outflow of $1 \mathrm{~km}^{2}$, etc. Water levels were measured automatically by sensors fitted in streams and remote transmission of primary data that are evaluated for each calendar year. The hydrological data of evaluated periods are summarized in Table 1.

$\mathrm{X}$-day flow rates are uninfluenced $\mathrm{Q}_{30}-\mathrm{Q}_{364}$. In 1986, new data were processed - those influenced by the manipulation for the fishing out of the Olsovec pond from the period 1969-1984. For the period 1969-1984, the 270-day flow rate is $0.026 \mathrm{~m}^{3} / \mathrm{s}$, the 355 -day flow rate is $0.0039 \mathrm{~m}^{3} / \mathrm{s}$, and $\mathrm{Q}_{364}$ is $0.001 \mathrm{~m}^{3} / \mathrm{s}$. The uninfluenced 100 -year flow rate for CHMI station is $26 \mathrm{~m}^{3} / \mathrm{s}$ after deduction of all transformations of ponds located in the basin. Uninfluenced flows and their values are flow rates after the impactors are deducted; influenced flows are flows that are computed with all interventions that are part of the river basin and are part of the flow. The $\mathrm{x}$-day flow rates have changed quite significantly over the periods, particularly at the lowest x-day flow rates. Compared to the original period 1931-1960, when $\mathrm{Q}_{355}$ was $10 \mathrm{l} / \mathrm{s}$, the flow rate was reduced to $3-4 \mathrm{l} / \mathrm{s}$. For $\mathrm{x}$-year flows, it is obvious how the flow would change if there was no pond system but only a natural flow.

The development of physical-chemical status of Jedovnice Brook was assessed on the basis of several monitoring campaigns from 1949 to 2014. The stream water was sampled below Jedovnice village, about $5 \mathrm{~km}$ upstream of the karst sinkhole. After commissioning the WWTP in 1998, the sampling point was located upstream of the WWTP. The results from years 1949 to 1998 were acquired by exploration of available literary sources. The monitoring campaign was performed by the Brno University of Technology in 2014 (Table 2).

Table 2. Details monitoring campaigns from 1949 to 2014.

\begin{tabular}{|c|c|c|c|c|c|}
\hline Year & 1949 & 1968 & $1971-1975$ & 1998 & 2014 \\
\hline Source & $\begin{array}{c}\text { Krejčí et al., 1951 } \\
{[14]}\end{array}$ & $\begin{array}{c}\text { Wünsch, 1969 } \\
{[15]}\end{array}$ & $\begin{array}{c}\text { Cigánek, 1976 } \\
{[16]}\end{array}$ & $\begin{array}{c}\text { Kuběnová, 1999 } \\
{[17]}\end{array}$ & $\begin{array}{c}\text { Schrimpelová, 2016 } \\
{[12]}\end{array}$ \\
\hline Number of samples & 1 & 3 & 41 & 2 & 13 \\
\hline
\end{tabular}


Comparison of the results is problematic with regard to the analytical methods used. Consideration should be given to the development of instrumentation in the field of sensitivity and accuracy. The following methods were used in 2014: dissolved $\mathrm{O}_{2}-$ Hach HQ40d multiparameter meter, BOD - standard dilution method, $\mathrm{NH}_{4}-\mathrm{N}$ - photometric determination $(425 \mathrm{~nm})$ with Nessler agent, $\mathrm{NO}_{3}-\mathrm{N}$ - photometric determination $(410 \mathrm{~nm})$ with sodium salicylate, $\mathrm{PO}_{4}-\mathrm{P}-$ photometric determination $(410 \mathrm{~nm})$ with ammonium molybdate [12]. The same methods were used in 1998-1999, except for the dissolved $\mathrm{O}_{2}$, which was determined iodometrically [17]. For earlier samplings, analytical methods were not indicated.

Mass flows of BOD, $\mathrm{NH}_{4}-\mathrm{N}, \mathrm{NO}_{3}-\mathrm{N}$, and $\mathrm{PO}_{4}-\mathrm{P}$ were calculated for measurements since 1971 (after the start of flow measurements) as follows:

$$
\begin{aligned}
& \text { 1971-1975: }(\mathrm{m}) \doteq \mathrm{c} \_(\mathrm{m}) \cdot \mathrm{Q}(1971-75)[\mathrm{kg} / \mathrm{d}] \\
& \text { 1998-1999: }(\mathrm{m}) \doteq \mathrm{c} \_(\mathrm{m}) \cdot \mathrm{Q}(1999)[\mathrm{kg} / \mathrm{d}] \\
& \text { 2014: }(\mathrm{m}) \doteq \mathrm{c} \_(\mathrm{m}) \cdot \mathrm{Q}(2014)[\mathrm{kg} / \mathrm{d}]
\end{aligned}
$$

...where $\mathrm{m}$ ' is mass flow, c_(m) is average concentration measured during the respective period, and Q is annual or five-year average flow.

Land use changes were evaluated based on the available numerical data and orthophoto images for the target area. Despite the fact that we used water monitoring campaigns from 1949 to 2014, the visual evaluation of land use changes proceeded from orthophoto images from 1953 provided by Military Geographical Service of the Armed Force of the Czech Republic [18] and from 2015 provided by the Czech Environmental Information Agency [19]. Numerical data of historical land use changes in the period 1949-2010 are available only for whole districts (not for individual municipalities). A detail analysis of land use changes exceeds the focus of this study. Therefore, the land use changes were expressed in the years 1948, 1990 and 2014 for the whole district of Blansko considering the similar development in the Jedovnice brook basin.
Demographic trends were monitored by basic demographic analyses (analysis of time series, fixed base index and chain index number). The relationship between the development of dates of physico-chemical status and demographic changes was determined using statistical methods (regression and correlation analysis).

\section{Results and Discussion}

\section{Land Use Changes between 1948 and 2014}

The changes in land use in the area of interest between 1948 and 2014 have been influenced in particular by rural collectivisation since the $1950 \mathrm{~s}$, bringing private farmers into united agricultural cooperatives. From an aerial image capturing the state in 1953 (Fig. 3), it is possible to distinguish forested areas (darker grey) and agricultural land (medium-dark and light grey) with a characteristic mosaic structure typical of small farmer farming. The consolidation of land characterized by a change in the size, shape and method of cultivation of agricultural land took place in the following period. These changes can be observed in the current aerial photograph (Fig. 3).

In terms of land use changes, the reduction of arable land $(-5.2 \%)$ in favour of other areas $(+5.3 \%)$ and permanent grassland $(+2.1 \%)$ occurred at the territory of the entire Blansko district between 1948 and 2014 (Fig. 4). The decline in forest areas between 1945 and $1990(-4.9 \%)$ was mainly caused by surface mining but occurred rather out of the study catchment area, where the forested area remained almost unchanged.

\section{Municipality and Demographic Analyses between Years 1950 and 2016}

The number of population total and houses, and population density is growing throughout the analysed period. The population increased from 5.266 (1950) to 6.406 (2016) inhabitants, the number of houses
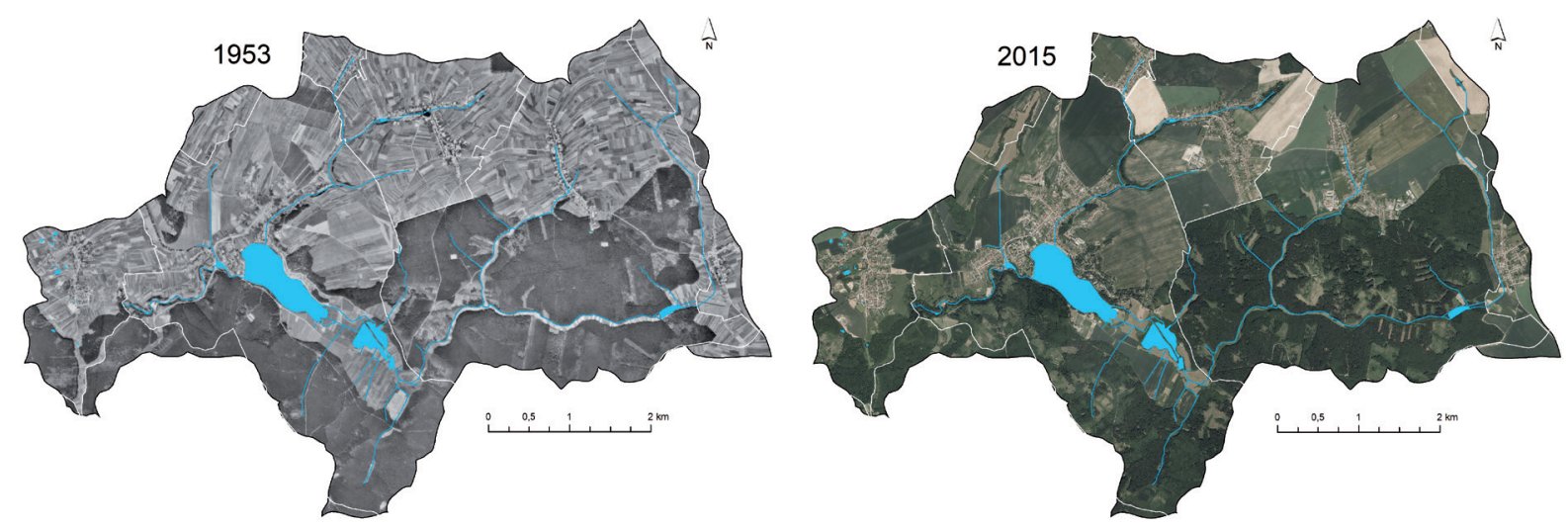

Fig. 3. Land use in 1953 (left) and 2015 (right) within the Jedovnice Brook water catchment area.

Source: Orthophoto 1953 provided by geoservice.army.cz [18] and orthophoto 2015 provided by CENIA.cz [19] 


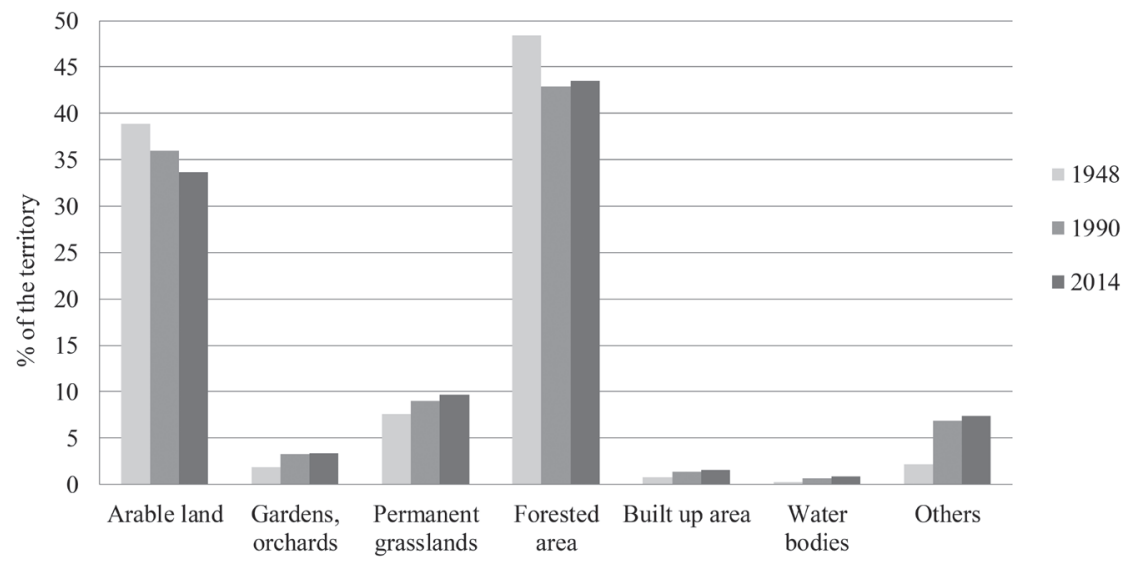

Fig. 4. Land use changes in the years 1948, 1990 and 2014 within the district of Blansko.

Source: author's compilation based on LUCC Czechia (Database of Long-term Changes in Usage of Czech Lands 1845-2000) [20]

increased from 1.225 (1950) to 2.055 (2016) and population density grew from 95.0 inhabitants $/ \mathrm{km}^{2}$ to 115.6 inhabitants $/ \mathrm{km}^{2}$.

The trend of population growth and number of houses is presented using the fixed base index and the chain index number (2015-2016). The fixed base index is rising throughout the analysis of the population by 21.6 percentage points (Fig. 5 left) and by the number of houses even by 67.8 percentage points (Fig. 5 right). The chain index shows important periods of population growth: after World War II and especially in the first decade of the $21^{\text {st }}$ century, when the influence of the suburbanization trend was significant. Growth in the number of houses is logically done before population growth. Average coefficient of population growth was $7.1 \%$ and of houses growth was $7.8 \%$ during the period $1950-2016$.

\section{Physical-Chemical Monitoring of the Basin between 1949 and 2014}

Average, minimum, and maximum results are presented in Figs 6-8. It is clear from the graphs that water quality of Jedovnice brook deteriorated in all monitored indicators between 1949 and 1998. Then, between 1998 and 2014, $\mathrm{O}_{2}$ saturation and organic matter improved and nitrogen stabilized while phosphorus continued to grow.

Oxygen saturation of unpolluted streams usually lies between $85 \%$ and 95\% [22]. As Fig. 6 (left) shows, average $\mathrm{O}_{2}$ saturation of Jedovnice Brook decreased between years 1968 and 1998 from almost 100\% to $47 \%$. Then, in 2014 , it rose to $69 \%$. $\mathrm{O}_{2}$ saturation usually shows indirect dependence on concentration of organic matter in water. In this sense, the development of $\mathrm{O}_{2}$ saturation agreed well with the BOD values (Fig. 6). The average BOD was $5.7 \mathrm{mg} / \mathrm{L}$ in 1968, $9.7 \mathrm{mg} / \mathrm{L}$ in $1971-75$, and $12.2 \mathrm{mg} / \mathrm{L}$ in 1998 . Then, until 2014, it dropped to $7.1 \mathrm{mg} / \mathrm{L}$. However, $\mathrm{O}_{2}$ saturation showed great variation and was affected also by season, water flow, and growth of green plants and algae.

Concentrations of nitrogenous substances in Jedovnice brook showed clear increases during the assessed period. A sudden change apparently occurred at the end of the 1960s/early 1970s (Fig. 7), when
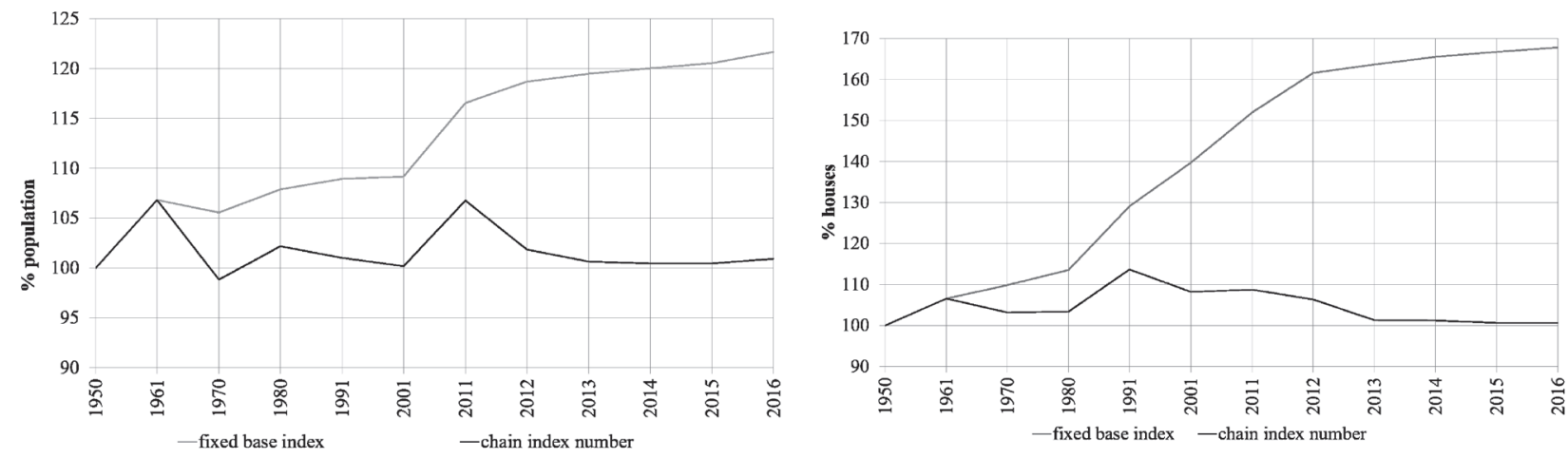

Fig. 5. The fixed basic and chain index of population (left) and number of houses (right) in cadastral areas of 7 municipalities of the water catchment area Jedovnice Brook between 2015 and 2016.

Source: author's compilation based on data of the Czech Statistical Office (population, \% houses) [21] 

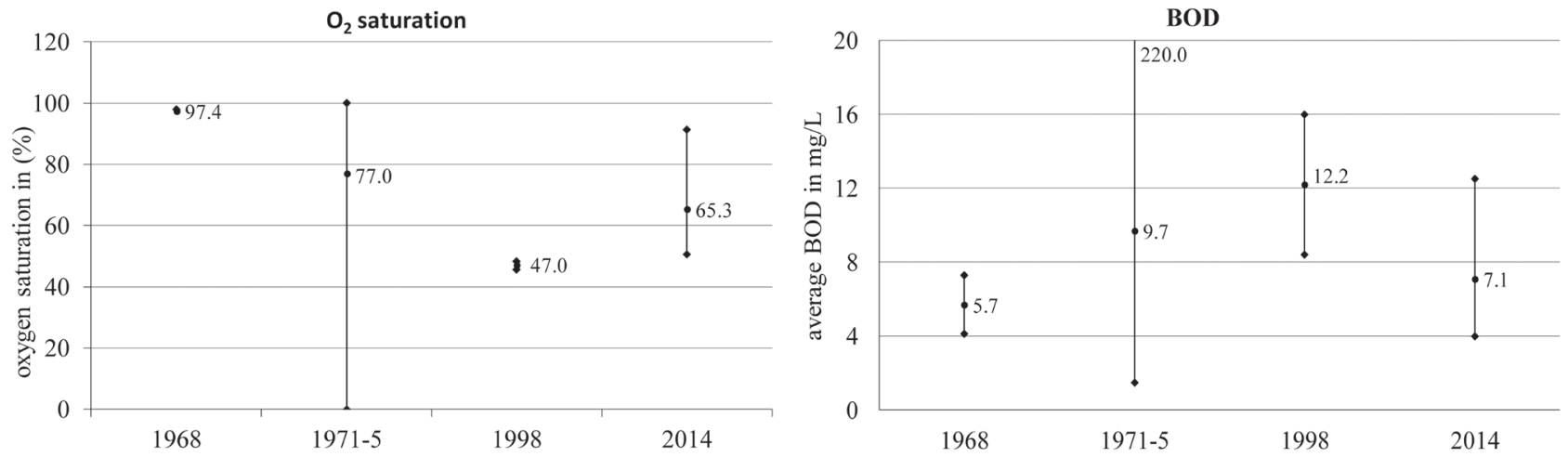

Fig. 6. Oxygen saturation (left) and BOD development (right) from 1968 to 2014.

Source: author's compilation based on own measurement
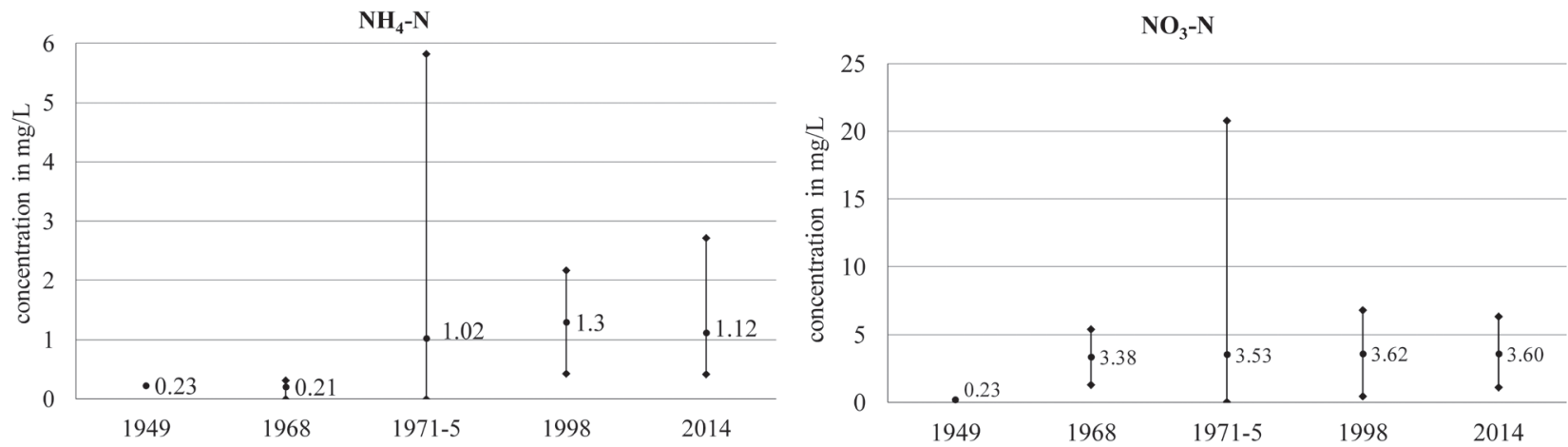

Fig. 7. $\mathrm{NH}_{4}-\mathrm{N}$ (left) and $\mathrm{NO}_{3}-\mathrm{N}$ concentrations (right) development from 1949 to 2014.

Source: author's compilation based on own measurement

the average $\mathrm{NH}_{4}-\mathrm{N}$ concentration increased from $0.2 \mathrm{mg} / \mathrm{L}$ to more than $1 \mathrm{mg} / \mathrm{L}$ (Fig. 7 left), and the $\mathrm{NO}_{3}-\mathrm{N}$ concentration from $0.2 \mathrm{mg} / \mathrm{L}$ to $3.5 \mathrm{mg} / \mathrm{L}$ (Fig. 7 right).

Concentrations of $\mathrm{PO}_{4}-\mathrm{P}$ greatly fluctuated and no reliable data were available in 1998. The average values showed an increasing trend from $0.07 \mathrm{mg} / \mathrm{L}$ in 1968 to $0.55 \mathrm{mg} / \mathrm{L}$ in 2014 (Fig. 8).

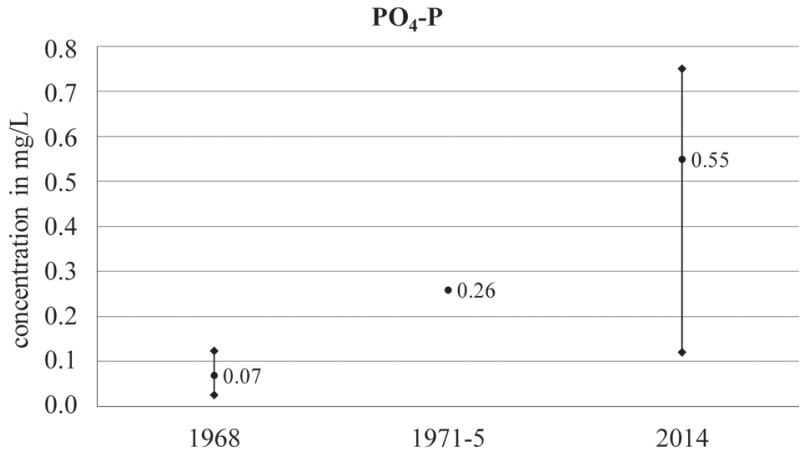

Fig. 8. $\mathrm{PO}_{4}-\mathrm{P}$ concentration development from 1968 to 2014. Source: author's compilation based on own measurement

\section{Influence of Human Activities}

The trend of the development of all assessed compound mass flows can be seen from Fig. 9. Impacts of human activities are not limited in time - they may be immediate or take years to decades to show any effects. However, many human activities have the potential to disturb hydrological exchange and biological activity beyond [23]. It is obvious that the observed values for the period 1949-2014 are influenced mainly by agricultural activities. The land use did not change significantly over time but there was a rather significant change in farming approaches. Small-scale farming was replaced by intensive farming on unified land with no balks using heavy technology and overusing industrial fertilizers in the 1960s. Currently, liquid and organic fertilizers are used, crop rotation has been improved and targeted grassing has been carried out on areas with incidence of sinkholes. Plant production prevails in the area now and the traditional way of farming in the form of grazing returns [24].

However, there was not a high degree of correlation between the mass flows of the selected compounds and the growth of the population in the catchment area of Jedovnicky Brook. Weak correlation exists 


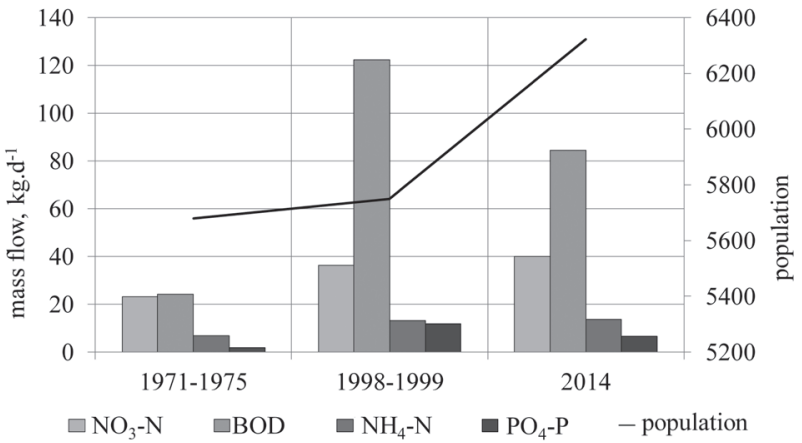

Fig. 9. Mass flows and population development of the water catchment area the Jedovnice Brook from 1971-1975 to 2014. Source: author's compilation based on own measurement

only between $\mathrm{NO}_{3}-\mathrm{N}$ and the population (0.68), and the other correlations are not statistically significant (Fig. 9).

Concentrations were monitored in the time period 1948-2014. According to the trend of the individual time series, the optimal function was determined. For the development of $\mathrm{NO}_{3}-\mathrm{N}$ concentrations, the most appropriate polynomial trend of the second degree $\left(\mathrm{R}^{2}=0.89\right), \mathrm{PO}_{4}-\mathrm{P}$ and $\mathrm{BOD}$ polynomials of the third degree $\left(\mathrm{R}^{2}=0.89\right.$ and 0.83 respectively) and the exponential trend for the $\mathrm{NH}_{4}-\mathrm{N}$ concentrations $\left(\mathrm{R}^{2}=0.71\right)$. Population development is best described by the polynomial trend of the second degree $\left(\mathrm{R}^{2}=1\right)$. It is possible to estimate developments in the near future on the basis of trends in the previous development of time series. It can be expected that concentrations of BOD and $\mathrm{NH}_{4}-\mathrm{N}$ will increase, as well as population size. The concentrations of $\mathrm{NO}_{3}-\mathrm{N}$ and $\mathrm{PO}_{4}-\mathrm{P}$ could decrease in the near future (Fig. 10). This prediction depends on the circumstances and is probable if the current situation does not change.

Water systems are very vulnerable in karst areas. The main source of pollution in the catchment area of Jedovnicky brook is agricultural activities, fish farming and population growth and changes in settlements. In

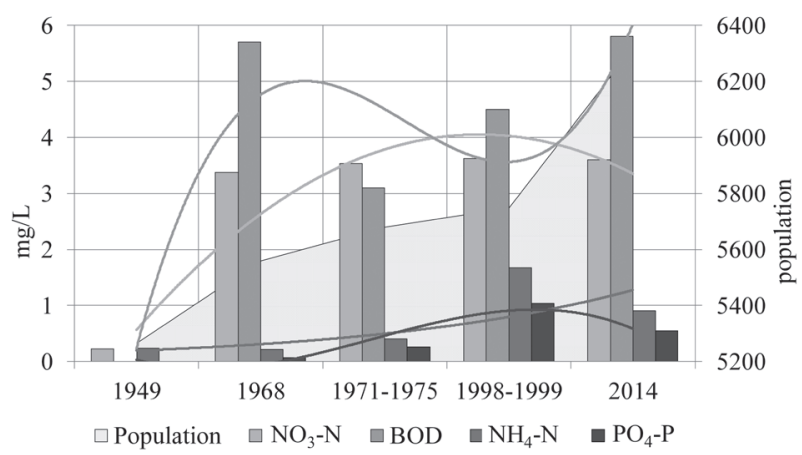

Fig. 10. Concentrations development of the water catchment area Jedovnice Brook from 1949 to 2014 and trends of time series in the context of population load.

Source: author's compilation based on own measurement the case of agricultural activities, the most important role of the transformation in the way of management in the history and the present time and the limitation of the use of industrial fertilizers in the area of PLA MK (this occurred in 1982) [24]. The values of $\mathrm{NH}_{4}-\mathrm{N}$ and $\mathrm{NO}_{3}-\mathrm{N}$ significantly increased in the $60 \mathrm{~s}$ and $70 \mathrm{~s}$ of the last century in Jedovnice Brook. $\mathrm{O}_{2}$ saturation was affected also by season. The development of $\mathrm{O}_{2}$ saturation agreed well with BOD values. From the point of view of fish farming there is an important system of ponds in the village of Jedovnice, which lies outside the PLA MK area, but it is bound to the Jedovnicky stream flowing directly into the karst area. In our case, $\mathrm{PO}_{4}-\mathrm{P}$ is introduced into the environment from point sources by sewage and household wastewater that passes WWTP without phosphorus removal technology. WWTP Jedovnice phosphorus removal technology now has disposal. The decline in $\mathrm{PO}_{4}-\mathrm{P}$ concentration and mass flow can be caused by the use of detergents with lower phosphate content. Since 2006, the sale of laundry detergents for household textiles has been prohibited in the Czech Republic [25].

The rising population of the river basin also plays a significant role in the burden on the quality of the aquatic environment, especially its dynamics after the year 2000 due to the strong suburbanization trend. The expanding built-up areas and the increasing amount of municipal wastewater is currently one of the most important risk factors for the eutrophication of surface waters in the PLA MK [26, 27]. In karst areas and areas communicating through the aquatic environment with these areas, it is necessary to pay special attention not only to the danger of discharging all waste treated and untreated water from settlements and recreational sites but also to the proper management of agricultural land. It is recommended to exclude the amelioration accelerating runoff, dumping waste in inappropriate places and the application of chemicals, including pesticides $[6,28]$.

Finally, it has become evident that not only for karst areas, the assessment of the quality of water in watercourses in the context of the entire catchment area is required $[29,30]$. The implementation of appropriate measures should be the priority within the entire catchment area not only in the area of the protected territory in the context of nature and landscape protection. At the same time, finding and influencing sources of groundwater contamination is an important step in improving overall environmental quality.

\section{Conclusions}

Water systems are very important and vulnerable components of karst areas. Our case study carried out at Jedovnice brook in Moravian Karst PLA, Czech Republic, confirmed that the big proportion of the karst streams pollution can be brought from the non-protected river basin by surface watercourses. 
A large part of Jedovnice brook watershed lies outside the PLA. Jedovnice brook enters its central part and brings water from the non-protected area to the karst territory. It sinks to the karst caves about $5 \mathrm{~km}$ downstream from the assessed sampling point. Our study evaluates hydrological, hydrochemical, demographical parameters, and land use gained in its watershed during six decades till the present time.

In terms of the hydrological situation, particularly the low flow rates decreased significantly during the assessed period. The x-year flows remained almost unchanged only thanks to the pond system on Jedovnice brook. It has come out of the hydrochemical assessment that Jedovnice brook is polluted already before entering the PLA, but it retains its self-cleaning ability on the surface. During the assessed period, water quality of Jedovnice brook deteriorated in all monitored indicators between 1949 and 1998. Then, between 1998 and 2014, $\mathrm{O}_{2}$ saturation and organic matter improved and nitrogen stabilized while phosphorus continued to grow.

Agricultural activities, population growth, and changes in settlements were identified as the main potential sources of Jedovnice brook pollution in the past. Agricultural activities have undergone major positive changes - especially in the method of management and the use of fertilizers. Currently, the rising population of the river basin, especially its dynamics after the year 2000 due to the strong suburbanization trend, the expanding built-up areas and the increasing amount of municipal wastewaters are the most important risk factors for the deterioration of Jedovnice brook water quality.

It has become evident that the implementation of appropriate measures in the context of nature and landscape protection should be the priority within the entire catchment area - not only in the established protected areas, such as Moravian Karst. At the same time, finding and influencing sources of water contamination is the most important step in improving overall environmental quality.

\section{Acknowledgements}

The Czech Science Foundation supported this work; grant No. 16-13231S Karstic water environment: the impact of human activities on "geomycobacteriology".

\section{Conflict of Interest}

The authors declare no conflict of interest.

\section{References}

1. JIANG Y. The contribution of human activities to dissolved inorganic carbon fluxes in a karst underground river system: evidence from major elements and $\delta^{13} \mathrm{C}(\mathrm{DIC})$ in Nandong, Southwest China. In. J. Contam. Hydrol. 152 (1), 1, 2013.

2. HILLEBRAND O., NÖDLER K., SAUTER M., LICHA T. Multitracer experiment to evaluate the attenuation of selected organic micropollutants in a karst aquifer. Sci. Total. Environ. 506-507, 338, 2015.

3. EINSIEDL F., RADKE M., MALOSZEWSKI P. Occurrence and transport of pharmaceuticals in a karst groundwater system affected by domestic wastewater treatment plants. J. Contam. Hydrol. 117, 26, 2010.

4. BUTSCHER C., AUCKENTHALER A., SCHEIDLER S., HUGGENBERGER P. Validation of a numerical indicator of microbial contamination for karst springs. Ground Water. 49 (1), 66, 2011.

5. MALÁ J., SCHRIMPELOVÁ K., TƯMA A., BÍLKOVÁ Z., HRICH K. Assessment of river water quality in the Moravian Karst, Czech Republic, [In:] International Multidisciplinary Scientific GeoConference Surveying Geology and Mining Ecology Management, SGEM. DOI: 10.5593/sgem2017/52/S20.011, 2017.

6. MODRÁ H., BARTOŠ M. HRIBOVA P., ULMANN V., HÜBELOVÁ D., KONEČNÝ O., GERŠL M., KUDĚLKA J., VOROŠ D., PAVLÍK I. Detection of mycobacteria in the environment of the Moravian Karst (Bull Rock Cave and the relevant water catchment area): the impact of water sediment, earthworm castings and bat guano. Veterinární medicína, 62 (3), 153, 2017.

7. LAN J.C., YANG P.H., REN K., CHEN X.B., XU X., HU $\mathrm{N}$. Investigation of nitrogen, phosphorus and microbial contamination in Laolongdong underground river system of Chongqing. Huan Jing Ke Xue. 35 (4), 1297, 2014.

8. ELLER K.T., KATZ B.G. Nitrogen Source Inventory and Loading Tool: An integrated approach toward restoration of water-quality impaired karst springs. Journal of Environmental Management. 196 (1), 702, 2017.

9. PAVLÍK I., HÜBELOVÁ D., KONEČNÝ O. Contribution to Health Geography: Sources of the contamination of surface waters and health risks in the Moravian Karst Protected Landscape Area. Geographia Cassoviensis. 11 (1), 33, 2017.

10. MíCHAL I. Ecological Stability. Veronica, Brno. 275, 1994 [In Czech]

11. REGIONAL INFORMATION SERVICE. Land use 2018. Municipalities in the Czech Republic. http://www.risy.cz, 2018 [In Czech].

12. SCHRIMPELOVÁ K. Comparison of the water quality of surface flow and karst conduit flow. Geol. výzk. Mor. Slez. 23 (1-2), 108, 2016.

13. CZECH HYDROMETEOROLOGICAL INSTITUTE. Basic hydrological characteristics of the target catchment area for the hydrological period 1931-1960, 1931-1980, 1981-2010. Unpublished data, 2017.

14. KREJČII J., KUBELKA V. Influence of the northern part of the Moravian Karst on the physico-chemical and bacteriological composition of allochthonic watercourses. Czechoslovak Karst 4. 1951 [In Czech].

15. WÜNSCH B. Adamov I-II Report on the results of hydrogeological investigations of Josefov-Bull Rock system. Geotest, Brno, Czech Republic 1969 [In Czech].

16. CIGÁNEK F. Report on the properties of Moravian Karst waters and their water use. KSVK Brno, Czech Republic, 1976.

17. KUBĚNOVÁ J. Monitoring of water quality in the Moravian Karst Protected Landscape Area. Diploma work. VŠCHT Praha, Czech Republic, 1999 [In Czech]. 
18. MILITARY GEOGRAPHICAL SERVICE OF THE ARMED FORCE OF THE CZECH REPUBLIC. Ortophoto 1953. Geoservice.army.cz, 2017.

19. CZECH ENVIRONMENTAL INFORMATION AGENCY. Ortophoto 2015. CENIA.cz, 2015.

20. LUCC Czechia. Database of Long-term Changes in Usage of Czech Lands (1845-2000). Research Center for Land Use Changes, Faculty of Science, Charles Czech Republic. http://web.natur.cuni.cz/ksgrrsek/lucc/index.php?scn=2, 2017.

21. CSO (Czech Statistical Office). Population and Housing Census 2011. Available at: https://www.czso.cz/ csu/sldb/ home, 2016.

22. PITTER P. Hydrochemistry. University of Chemistry and Technology, Prague. 792, 2015.

23. HANCOCK P.J. Human impacts on the streamgroundwater exchange zone. Environmental Management, 29 (6), 763. https://doi.org/10.1007/s00267-001-0064-5, 2002.

24. SKOŘEPA, H., TŮMA, A. CHKO Landscape protected Area Moravian Karst 60 years. ŽIVA - The view in the field of nature all 6 Academia Publishing, SSČ AV ČR, v. v. i., http://ziva.avcr.cz/2016-6/chko-moravsky-krassedesatileta.html, 2016 [In Czech].

25. Ministry of the Environment of the Czech Republic. Decree No. 78/2006 Coll. on the list of dangerous chemicals.

26. MANDER U., KULL A., KUUSEMETS V., TAMM T. Nutrient runoff dynamics in a rural catchment:
Influence of land-use changes, climatic fluctuations and ecotechnological measures. Ecological Engineering. 14 (4), 405, 2000.

27. HOLLAND A.F., SANGER D.M., GAWLE CH.P., LERBERG S.B., SANTIAGO M.S., RIEKERK G.H.M., ZIMMERMAN L.E., SCOTT G.I. Linkages between tidal creek ecosystems and the landscape and demographic attributes of their watersheds. Journal of Experimental Marine Biology and Ecology. 298 (2), 151. https://doi. org/10.1016/j.scitotenv.2014.10.102, 2004.

28. ANDREO B., GOLDSCHEIDER N., VADILLO I., VIAS J.M., NEUKUM C., SINREICH M., JIMENEZ P., BRECHENMACHER J., CARRASCO F., HOTZL H., PERLES M.J., ZWAHLEN F. Karst groundwater protection: First application of a Pan-European Approach to vulnerability, hazard and risk mapping in the Sierra de Líbar (Southern Spain). Sci. Total. Environ. 34 (3), 54, 2006.

29. WILLIAMS A., KIMBALL M. Evaluation of longterm trends in hydrographic and nutrient parameters in a southeast US coastal river. Environmental Monitoring. 185 (12), 1049, DOI: 10.1007/s10661-013-3347-4, 2013.

30. PASZTALENIEC A., KUTYŁA S. The Ecological Status of Lakes in National and Landscape Parks: Does the Location of a Lake and Its Catchment within a Protected Area Matter? Polish Journal of Environmental Studies. 24 (1), 227, DOI:10.15244/pjoes/24926, 2015. 